\title{
"Governance and Provision of Health Security: A Case Study of the Implementation of the National Rural Health Mission Programme in East Khasi Hills District of Meghalaya"
}

\author{
Priyanka K. Nongkynrih, \\ Assistant Professor, Department of Political Science, St. Mary's College, Shillong, India
}

\begin{abstract}
The provision of human security in terms of food and health by the Government is an important indicator of good governance. This is more so in a state which is largely rural in nature, where the poverty level is high and the basic access to healthcare facilities is negligible. The health indicators in the state of Meghalaya are not too impressive. Infant Mortality Rate is as high as 55(SRS 2011) and it is reported that one in every four children is severely underweight (NFHS 3). To add to this the health indicators of women is also far from good. The state has a high Maternal Mortality Rate as well as high Total Fertility Rate. The NRHM Vision (20052012) has identified Meghalaya as one of the states having weak public health indicators and infrastructure. The weak health indicators and infrastructure bears testimony to the fact that until and unless the Government takes a more proactive role, large group of the marginalized section will not enjoy any form of health security. In this context therefore it becomes important for us to understand the role played by the National Rural Health Mission (NRHM) in ensuring health security to the marginalised group. Both primary and secondary sources have been used. Primary sources included government reports and document; while Secondary sources included the use of reference books and newspapers.
\end{abstract}

Keywords: East Khasi Hills, Health Security, Infant Mortality Rate, Maternal Mortality Rate, National Rural Health Mission.

\section{Introduction:}

Reduction of mortality rate in children below five years by two-thirds; reducing the Maternal Mortality Rate (MMR) by three quarters and reducing the occurrence of diseases like malaria and spread of HIV/AIDS by 2015 are some of the targets set to be achieved under the Millennium Development Goals adopted at the United Nations Millennium Summit 2000. India being a signatory to the Millennium Development Goals it therefore becomes important for the Government to come up with policies trying to reach these targets. Under such circumstances the concept of good governance has become all the more important. An important factor of good governance is the provision of food and health security to the people and this can be ensured by a committed and proactive government. This becomes all the more necessary in a state which is characterised by high incidence of poverty and poor health indicators. It therefore becomes an important task for the government to provide affordable healthcare facilities to the marginalised group as getting access to healthcare facilities by such group becomes difficult. Taking into consideration the poor health indicators prevailing in the country especially when it relates to the health of women and children, the Government of India in April 2005 launched the NRHM, an intensive programme to address the health issues of the people living in the rural areas. The NRHM's main objective is to provide basic primary healthcare services to the rural population which is affordable and effective. The main focus group has been women and children living in rural areas. The NRHM's Mission Document states the basic aim of the NRHM as strengthening rural hospitals; providing female health activists in each village to reach out to the community; linking provisions of safe drinking water and sanitation with better health of the people; providing emergency and referral transport to every village; involving Panchayati Raj Institutions and Self Help Groups; reviving local traditional health practice. The progress of NRHM in a state is monitored by the State Health Mission under the Chief Minister.

This paper aims at looking at the role of the government in terms of ensuring health security to the marginalized group in East Khasi Hills District of Meghalaya through the NRHM Programme. The major objectives of this Paper are:

- To look at the prevailing health indicators in the District and see how the NRHM Programme is able to address the issue of health security

- To understand the working and implementation of the NRHM

- To analyse the achievements and problems faced in the successful implementation of the NRHM

- To suggest measures to ensure better performance of the NRHM. 


\section{Health Profile of Meghalaya}

The NRHM has listed Meghalaya as one of the 18 High Focus State. This was done on the basis of the prevalence of weak health indicators and infrastructure in the state. Meghalaya came into existence as a state on January $21^{\text {st }} 1972$. However despite forty years of existence as a state its performance in terms of health indicators has not been impressive. The state with a population of 29.64 lakhs (2011 Census) is made up of 11 districts 4 of which have been recently added. It is largely a rural agrarian economy with high incidence of poverty. As per the 2002 survey conducted by the Department of Community and Rural Development, Government of Meghalaya, $48.70 \%$ of the population in the state has been categorized as falling under the Below Poverty Level. With a huge population of the state categorized as BPL it becomes an important task for the government to see to it that affordable and accessible health care facilities are provided to the people especially to those belonging to the marginalised community. Five districts of the state have been categorized as High Focus District where special attention has been given.

The status of the health of women and children is an important factor indicating the well being of a state. A closer look at the health indicators of the state will show that in terms of the health of women and children the state has not been able to perform well. Meghalaya is amongst one of the states whose IMR stands well above the Millennium Development Goal of 30. It also has one of the highest Infant Mortality Rate (IMR) amongst the smaller states in the country (SRS Bulletin, December 2011).

Table1: Infant Mortality Rate in Meghalaya

\begin{tabular}{|l|l|}
\hline Sample Registration System (SRS) & $\begin{array}{c}\text { Health Management Information System } \\
\text { (HMIS) }\end{array}$ \\
\hline $56(2007)$ & \\
\hline $58(2008)$ & \\
\hline $59(2009)$ & $26.22(2009-10)$ \\
\hline $55(2010)$ & $40.42(2010-11)$ \\
\hline $55(2011)$ & $20.00(2011-12)$ \\
\hline
\end{tabular}

Source: compiled from SRS Bulletin and HMIS Report

As per the SRS survey Meghalaya's IMR has always stood above 50 in the past five years. The other health indicators of children in the state are not impressive either. The National Family Health Survey 3 (200506) reports that in Meghalaya one in every four children is severely underweight and the percentage of children (6-35 months) with anaemia is as high as $64 \%$.

Despite the fact that the tribes of Meghalaya are largely matrilineal the health indicators reflecting the condition of women has not been too encouraging either. The health indicator of women in the state reflects the poor state of affairs. Meghalaya has a high MMR which stands at 264.87 (Health Statistical Handbook 2011-12) well above the national average of 212 (SRS 2011). Anaemia is also very high amongst women more so in the case of pregnant women. As per the NFHS 3 survey $64 \%$ of pregnant women in the state suffer from anaemia. Another alarming figure indicating the poor state of women's health is the prevalence of high fertility rate. As per the NFHS 2 survey Meghalaya has one of the highest fertility rate in the country standing at 4.6. The NFHS 3 report puts Meghalaya's Total Fertility Rate (TFR) at 3.8 well above the national average of 2.8 .

\section{Working of NRHM in East Khasi Hills}

East Khasi Hills with a population of 824059 (2011 Census) is one of the most highly populated district in Meghalaya. There are eight Blocks in the District. The incidence of poverty in the district too is significantly high. As per the 2002 survey conducted by the Community and Rural Development Department (C\&RD), Government of Meghalaya, $46.93 \%$ of the population in the District falls under the BPL category.

Table 2: BPL Census of East Khasi Hills

\begin{tabular}{|l|l|l|l|}
\hline & Total household & BPL household & BPL\% \\
\hline $\begin{array}{l}\text { Blocks in East } \\
\text { Khasi Hills }\end{array}$ & 107679 & 50539 & $46.93 \%$ \\
\hline Mylliem & 35,876 & 10936 & $30.65 \%$ \\
\hline Mawphlang & 14691 & 9282 & $63.18 \%$ \\
\hline Mawsynram & 10124 & 6494 & $64.14 \%$ \\
\hline $\begin{array}{l}\text { Shella- } \\
\text { Bholaganj }\end{array}$ & 9069 & 4280 & $47.19 \%$ \\
\hline Pynursla & 12272 & 6988 & $56.14 \%$ \\
\hline Mawryngkneng & 10988 & 5236 & $47.65 \%$ \\
\hline Mawkynrew & 8556 & 3970 & $46.40 \%$ \\
\hline
\end{tabular}




\begin{tabular}{|l|l|l|l|}
\hline Khatarshnong & 6303 & 3353 & $53.20 \%$ \\
\hline
\end{tabular}

Source: 2002 Survey, C\&RD Dept., Government of Meghalaya, www.megcnrd.nic.in/ retrieved on $20^{\text {th }}$ September 2012

Though East Khasi Hills does not fall under the High Focus District (Difficult Areas), the health indicators however are not too impressive. The MMR prevalent in East Khasi Hills is well above the national average and the IMR in the district interestingly stands well above the IMR in the state. As per the HMIS indicators, in the past three years it has stood above the targeted goal of 30 as laid down under the Millennium Development Goals. The presence of high level of IMR and MMR reflects the poor health status of women and children in the District.

Table 3: Health indicators in East Khasi Hills

\begin{tabular}{|c|c|l|l|}
\hline East Khasi Hills & HMIS 2009-10 & HMIS 2010-11 & HMIS 2011-12 \\
\hline IMR & 32.49 & 52.49 & 34.85 \\
\hline MMR & 294.17 & 279.14 & 226.71 \\
\hline
\end{tabular}

Source: Health Statistical Handbook 2011-12, Meghalaya NRHM, HMIS Division

The prevalence of poor health indicators coupled with high incidence of poverty has made the Government's role all the more crucial. The launching of the NRHM in the state had brought about a ray of hope. There was high expectation that the NRHM will cater to the needs of the rural population and make healthcare facilities accessible to all. A number of changes were brought about in the provision of healthcare facilities with the adoption of the NRHM; the number of health institutions was increased substantially, Accredited Social Health Activists (ASHA) were established in the villages, health camps and mobile clinics were organized in different parts of the district, a health insurance scheme to benefit the BPL population was initiated, emergency response units were set up, village sanitation committee to maintain cleanliness of the villages and localities were established, and to ensure better healthcare services to the public in general a number of Community Health Centres (CHC), Primary Health Centres (PHC) and sub-centres in remote areas of the districts were handed over to voluntary and Non Governmental Organisations.

In order to cater to the needs of the poorer section especially those belonging to rural areas the number of health institutions in the form of CHCs and PHCs was increased

Table 4: Number of Health Institutions in East Khasi Hills

\begin{tabular}{|l|l|}
\hline No. of Blocks & 8 \\
\hline Hospitals & 3 \\
\hline District Hospitals & 3 \\
\hline CHC & 6 \\
\hline PHC & 23 \\
\hline State Dispensary & 5 \\
\hline Urban Health Centres & 13 \\
\hline Sub Centres & 66 \\
\hline Private Hospitals & 6 \\
\hline
\end{tabular}

Source: Meghalaya HMIS Delivery Analysis 2011-12, NRHM, Govt. of Meghalaya www.meghealth.nic.in/nrhm/hmis.html retrieved on 30th January 2013

Meghalaya has 6258 ASHA and East Khasi Hills alone has 1033 ASHA located in 1033 villages of the district (Health Statistical Handbook 2011-12). The main objective of having an ASHA was to provide community level healthcare services, and to mobilize the community to get access to healthcare facilities. In Meghalaya the State ASHA Resource Centre has been set up to support and strengthen the ASHA programme in the state. Every trained ASHA has been provided with a Drug kit, Uniform, Bag, Diary and Raincoat. ASHA acts as a link between the health centres and the villagers. The ASHA is trained to advise villagers about health, sanitation, hygiene, contraceptive; to provide medical treatment to minor problems like diarrhoea, minor injuries and to escort sick villagers to the health centres. The ASHAs have been playing a critical role in mobilizing the villagers in availing healthcare facilities especially during pregnancy.

The Village Health and Sanitation Committees have been set up in all the 1021 villages under the District (Health Statistical Handbook 2011-12). The main objectives of the VHSC are getting involved in village level cleanliness drive, sanitation drive, conducting school level health activities.

Another means of reaching out to the villagers in the remote areas is conducting regular Health Melas. In East Khasi Hills 2 Health Melas, 10 Outreach Camps, 421 Focused Group Discussion at community level on health issues, 454 Counselling Sessions at community level and 103 Health Camps were held by the Mobile Medical Unit in 2011-12 (NRHM Annual Report 2011-12, District Health Society). 
The government has started the Integrated Emergency Management Response Institute (EMRI) since 2009. The number of ambulances available in $29 \mathrm{CHC} / \mathrm{PHC}$ of East Khasi Hills is merely 10 with some CHC/PHC having no ambulance facility at all (Health Statistical Handbook 2011-12). In such circumstances the 108 emergency services provided by EMRI have proved to be a blessing for many of the villagers.

The state Government has initiated Homoeopathy and Ayurveda wing in all district hospital in the state. There are 15 PHC and CHC in East Khasi Hills with AYUSH centres (Health Statistical Handbook 201112). These centres are popular with the masses as majority of the people still prefer ayurvedic and homoeopathic treatment.

Provision of health insurance in a state with high incidence of poverty becomes a necessity especially for the marginalised community to avail health care facilities. Keeping this in mind the Central Government launched the Rashtriya Swastha Bima Yojna (RSBY), a health insurance scheme for the people living Below the Poverty Line. Beneficiaries of RSBY are entitled to a coverage of Rs. 30,000 for most of the disease that require hospitalization. The scheme started operating from $1^{\text {st }}$ April 2008; the Government of Meghalaya started the enrollment from $1^{\text {st }}$ January 2009. In all five districts have been selected.

The Rogi Kalyan Samiti (Hospital Management Committee) has been started in all CHC, PHC and District Hospitals. In East Khasi Hills RKS have been constituted in 3 District Hospitals, 6 CHCs and 22 PHCs. The main activities of the RKS involves improvement and maintenance of physical infrastructure in hospitals, maintenance of cleanliness, sanitation and beautification of campus, provision of essential amenities, purchase of minor medical equipments and instruments (NRHM Annual Report 2011-12).

To tackle the shortage of qualified medical staff in remote health institutions the government has involved private partners under the Public Private Partnership (PPP) mode to run the Sub Centres, CHCs and PHCs. Infrastructure, building, medicine will be provided by the Government while the NGOs and Voluntary Agencies will be entrusted with provision of skilled manpower- doctors, nurses. They will have their own medical and paramedical team. They will provide healthcare services as provided by the CHCs and PHCs.

Table 5: NGO/ Voluntary Association operating in East Khasi Hills under PPP mode

\begin{tabular}{|l|l|l|}
\hline Name of NGO/ Voluntary Association & Selected CHC/ PHC & Block \\
\hline Karuna Trust, Bangalore & Mawsahew PHC & Shella Bholaganj \\
\hline Karuna Trust & Mawlong PHC & Shella Bholaganj \\
\hline Voluntary Health Association of Meghalaya (VHAM), Shillong & Jatah PHC & Mawkynrew \\
\hline VHAM & Dangar PHC & Mawsynram \\
\hline Citizens Foundation, Jharkhand & Ichamati CHC & Shella Bholaganj \\
\hline
\end{tabular}

Source: Health Statistical Handbook 2011-12, Meghalaya NRHM, HMIS Division

The VHAM also operates two sub-centres (Nohrun, Sonatola) in the district. The CHC/PHC were handed to these NGOs in 2009. In a period of just over three years they have recorded good performance especially in terms of OPD attendance and institutional deliveries.

Table 6: OPD attendance after CHC/PHC were taken over

\begin{tabular}{|l|l|l|l|l|}
\hline Name of CHC/PHC & $\begin{array}{l}\text { Before taking over } \\
2008-09\end{array}$ & $\begin{array}{l}\text { After taking over } \\
2009-10\end{array}$ & $\begin{array}{l}\text { After taking over } \\
2010-11\end{array}$ & $\begin{array}{l}\text { After taking over } \\
2011-12\end{array}$ \\
\hline Ichamati CHC & 9234 & 10718 & 15916 & 15215 \\
\hline Jatah PHC & 14389 & 18947 & 17182 & 18955 \\
\hline Dangar PHC & 8288 & 14350 & 7899 & 9056 \\
\hline Mawlong PHC & 5270 & 7449 & 12051 & 9271 \\
\hline Mawsahew PHC & 3046 & 4506 & 4173 & 5463 \\
\hline
\end{tabular}

Source: NRHM Annual Report 2011-12, District Health Society, East Khasi Hills, Meghalaya

Table 7: Number of Institutional Deliveries in the CHC/PHC after being taken over

\begin{tabular}{|l|l|l|l|l|}
\hline Name of CHC/PHC & $\begin{array}{l}\text { Deliveries before } \\
\text { taking over 2008-09 }\end{array}$ & $\begin{array}{l}\text { Deliveries after taking } \\
\text { over 2009-10 }\end{array}$ & $\begin{array}{l}\text { Deliveries after taking } \\
\text { over 2010-11 }\end{array}$ & $\begin{array}{l}\text { Deliveries after } \\
\text { taking over 2011- } \\
12\end{array}$ \\
\hline Ichamati CHC & 4 & 33 & 63 & 73 \\
\hline Jatah PHC & 0 & 10 & 19 & 45 \\
\hline Dangar PHC & 0 & 2 & 6 & 6 \\
\hline Mawlong PHC & 0 & 2 & 21 & 25 \\
\hline Mawsahew PHC & 0 & 11 & 14 & 34 \\
\hline
\end{tabular}

Source: NRHM Annual Report 2011-12, District Health Society, Meghalaya 
The figures in the above Tables ( 6 and7) suggest that there has been a major improvement in the number of patients visiting the PHCs and CHCs after they had been taken over by the voluntary organisations and NGOs and the number of deliveries at the $\mathrm{PHC} / \mathrm{CHC}$ has also significantly improved. The management has transformed the stereotypical foul-smelling PHC into pleasant health institutions (Assam Tribune, May $27^{\text {th }}$ 2011). The involvement of private organisations in running the CHCs and PHCs to a large extent has helped the government in implementing the goals laid down under the NRHM. The VHAM which is operating a number of CHCs and PHCs is one of the Mother NGO operating in East Khasi Hills District.

\section{Problems in the Implementation of NRHM}

The adoption of the NRHM programme no doubt has brought about transformation in the provision of healthcare services; however it is plagued with a number of problems and difficulties. In many respects the goals and targets set forth by the project has not been met. While many states have been able to bring down the IMR, MMR and TFR it is not so in the case of Meghalaya. A number of factors have clipped the successful working of the NRHM.

Firstly there is a shortage of medical staff to run the PHCs and the CHCs. Many of the CHCs and PHCs are running without any doctors, thus making the existence of such health institutions obsolete. The villagers have to come to the hospitals in the towns to get access to healthcare facilities. Many of these institutions are running without any specialists as the doctors are unwilling to serve in the rural areas due to the lack of facilities and incentives. This has also resulted in the loss of lives as in the case of a two and half year old child from Pyndensohsaw near Mawsynram who was suffering from dysentery but died only because there was no doctor available at the PHC in Tyrsad, East Khasi Hills (Shillong Times, December $27^{\text {th }}$, 2011).

Secondly, the deplorable condition of the roads has made it difficult for healthcare facilities to reach out especially to the remote areas. In fact there are villages which are still not connected by road. In East Khasi Hill alone there are 124 villages which are not accessible (Health Statistical Handbook, 2011-12). Villagers have to travel a large distance before reaching the nearest PHC/CHC. This becomes more of a problem when the patient is sick or a woman is about to deliver a child. This leaves them with no other option but to turn to local medical practitioner or resort to home delivery thus putting both the child and mother at risk.

Thirdly, the state continues to have a high fertility rate and the problem lies in the people's non acceptance of family planning measures. The size of the family continues to be large. Women continue to bear many children thus taking a toll on her health. The use of contraceptives and other birth control measure was low in the state (NFHS3). In East Khasi Hills female sterilization in 2011-12 was a mere $2 \%$ as against $0.03 \%$ male sterilization (NRHM Annual Report 2011-12). The religious practice of the people and the lack of awareness are largely responsible for preventing the people from using birth control measures.

Fourthly, another alarming trend prevailing in the state is with regards to the number of deliveries taking place at home. As per the NFHS 3 Report Meghalaya has one of the lowest proportions of birth taking place in a health institution - 71\% of birth in the state takes place at home and only $29 \%$ in a health institution. The high incidence of delivery taking place at home has further increased the risk of both mother and child.

The fifth problem faced in the successful implementation of the NRHM is a deficiency of physical infrastructure. The number of PHC, CHC and sub-centres are falling short of those sanctioned. Out of 30 PHCs sanctioned only 22 are operating; 67 out of 75 sanctioned sub centres are operating; and 6 out of 7 sanctioned CHCs are operating (PIP 2010-11www. pipnrhm-mohfw.nic.in/.../Meghalaya). For a population of more than eight lakhs three public hospitals and six private hospitals are available. This takes a toll on the villagers especially those belonging to the marginalised group as they have no means to avail healthcare facilities. The Civil Hospital one of the 3 Hospitals in the District is overcrowded. Lack of space has led to the hospital management putting up patients in the corridors. Many of the $\mathrm{CHCs} / \mathrm{PHCs}$ in the villages are running without water and electricity. East Khasi Hills till date has just 1 District Hospital (Ganesh Das Hospital) catering exclusively to mother and child care.

Sixthly there have been complains of shortage of equipment and medicines. As per the HMIS 2011-12 Report the number of institutions having operational Sick New Born and Child Care Units is in the entire East Khasi Hills District is merely 17. There are often complains that there is shortage of medicines available in the dispensaries and hospitals. Patients have to purchase the medicines from outside thus creating a problem for the poor who cannot afford. Despite funds being spent on maintenance of health institutions run by the government, a lot is still left to be done. Recently in a shocking incident at Civil Hospital, Shillong, it has been reported that rats were biting off a dead corpse (Meghalaya Times, $21^{\text {st }}$ June, 2012). This incident reflects the deplorable condition of state run health institutions.

NRHM faces another uphill task of reaching its goal as the immunization level in the state is very poor. As per the NFHS 2 survey the percentage of children between 0-11 months of age fully immunised was $14.3 \%$ which jumped up marginally to $32.8 \%$ (NFHS 3). As per the HMIS report the percentage of children between 0-11 months who have been fully immunized was $45 \%$ in 2009-10 which went up to $60 \%$ in 2010-11 
(PIP 2010-11 www. pipnrhm-mohfw.nic.in/...Meghalaya). The presence of the above mentioned hindrances and obstacles to a large extent has hampered the successful implementation of the NRHM programme.

\section{Conclusion:}

The adoption of the NRHM has brought about improvements in the number of health institutions available and it has also made healthcare facilities accessible to villagers in far flung remote areas which would have otherwise remained ignored. However the government needs to play a more proactive role in delivering better health services to the people. Efforts should be made to reach the goals set forth under the Millennium Development Goals 2000. Despite a number of improvements being brought about by the NRHM in the health services the prevailing health indicators in Meghalaya especially relating to women and children has still not been able to show much improvement. The thrust area of the NRHM has been women and children, however, looking at the prevailing health indicators- IMR, MMR, and TFR, anaemia amongst women and children, underweight and undernourished children a lot still needs to be done. The overall success of the Mission will not be possible without taking a holistic approach. A number of factors need to be taken into consideration. Health indicators will not show remarkable improvement without the people having access to nutritious food, safe drinking water, hygienic condition of living and better infrastructural facilities. It will be pointless to have mobile emergency response units when there is no road connecting the villages. Setting up CHCs/PHCs without adequate manpower and facilities will be of no use as they will not be able to act as First Referral Units. Government too must be committed in its efforts to see that the healthcare facilities are functioning, equipments and medicines are available and healthcare providers are available in these facilities.

The most basic criteria that will determine the health of an individual is addressing the issue of food security. High incidence of anaemia, malnourishment and underweight children is also linked to the non availability of nutritious food. The government needs to address the question of food security more seriously. Knowing very well that the state has a high population living Below the Poverty Line food delivery mechanisms to the marginalised group should be in place. Until and unless the question of food security is addressed possibilities of health indicators improving are minimal. Sincere efforts should be made by the government to distribute nutritious food to the marginalised group.

The involvement of voluntary organisations and NGOs in the health sector should be increased as it has been seen that PHCs and CHCs run by such organisations have shown remarkable improvement. Involvement of the Dorbar (local traditional political institutions prevailing in East Khasi Hills) should also take place as this will lead to more accountability, monitoring and transparency. Since the Dorbars work at the grassroot level they would be in a position to monitor the working of the institutions.

The level of awareness should also be increased so that people will come forward in taking advantage of improved technologies available in healthcare institutions. Much more needs to be done in breaking the myth of people when it comes to immunization of children and adopting family planning measures. Local health care practitioners are still very popular amongst the tribal community; the government should therefore try to rope them, in providing healthcare facilities in certain areas. NGOS and Dorbars should also come forward in creating awareness amongst the people. The government has a mammoth task to perform in ensuring that healthcare facilities for all are available. The question of good governance- transparency, accountability, community- level participation, committed government comes into play in ensuring better healthcare facilities to the common man. The NRHM will not bear fruitful results until and unless a committed government is in place to ensure that the goals set forth under it are achieved.

(The Research Paper is part of the Paper presented at the National Seminar on "Governance, Socio Economic Disparity and Social Unrest in the Scheduled Areas of India" organised by the Tata Institute of Social Science, Guwahati campus from the $22^{\text {nd }}-24^{\text {th }}$ November 2012.)

\section{References:}

Reports and Documents:

[1] United Nations Millennium Summit 2000, www.un.org/millennium/summit.htm retrieved on 22 nd September 2012

[2] National Rural Health Mission (2005-2012) Mission Document, www.mohfw.nic.in/NRHM/Documents/Mission_Document retrieved on 20th September 2012

[3] SRS Bulletin, New Delhi, Volume 46, No. 1, December 2011

[4] National Family Health Survey 3 (2005-06), Ministry of Health and Family Welfare, Government of India

[5] Dept. of Community and Rural Development, Government of Meghalaya www.megcnrd.nic.in/ retrieved on $20^{\text {th }}$ September 2012

[6] National Rural Health Mission, Govt. of Meghalaya, www.meghealth.nic.in/nrhm/hmis.html retrieved on 30 th January 2013

[7] Health Statistical Handbook 2011-12, HMIS Division, NRHM, Meghalaya

[8] Sample Registration System 2011

[9] NRHM Annual Report 2011-12, District Health Society, East Khasi Hills, Meghalaya

[10] State Programme Implementation Programme 2010-11 www.pipnrhm.mohfw.nicin/.../Meghalaya retrieved on 24th September 2012

Articles in Newspapers:

[11] Das Raju, Private participation helping NRHM in Assam Tribune, May $27^{\text {th }} 2011$

[12] State's Rural Healthcare System in Shambles in Shillong Times, December $27^{\text {th }} 2011$

[13] Rats devour dead body at Shillong Civil Hospital morgue in Meghalaya Times, $21^{\text {st }}$ June, 2012 